\title{
DESIGN PARAMETERS OF BUFFER STOPS
}

\author{
Petr Guziur
}

\begin{abstract}
Brno University of Technology, Faculty of civil engineering, Veveři 331/95, 60200 Brno
correspondence: guziur.p@fce.vutbr.cz
\end{abstract}

\begin{abstract}
Paper discuses reasons of building buffer stops and situations that may occur in railway station leading to build safety tracks. Also discusses parameters of buffer stops that enter its design, such as collision speed and kinetic energy absorbing capacity. Furthermore, presents categories of buffer stops depending on principles of absorbing the kinetic energy and points pros and cons of each structure.
\end{abstract}

KEYWORDS: Buffer stop, kinetic energy, braking force, dead-end track.

\section{INTRODUCTION}

Buffer stop is a device at the end of dead-end track or closed track with a purpose to stop the rolling stock. In Czech Republic it is allowed to use three types of buffer stops (according to national regulation ČD Ž9 [1). All three types are fixed (rigid) construction, yet there are numerous designs of buffer stops used abroad. We can divide buffer stops in categories depending on the principles of absorbing the kinetic energy, which is the most important parameter of buffer stops. As basic categories we can name fixed buffer stops, hydraulic buffer stops and friction buffer stops. Every type has its pros and cons and suitable place to be installed (depending on circumstances).

\subsection{Flank Protection}

One of the places, where buffer stop has to be installed, is the end of safety track which represents direct flank protection of train paths. There are two types of flank protection of train path:

- direct flank protection - protection of rolling stock from non-permitted ride of rolling stock from side approaching track - flank protection switch or derail is used,

- indirect flank protection - protection of rolling stock from non-permitted ride of rolling stock from side approaching track - signals with prohibiting signal is used.

And there are different conditions for flank protection of train path with speed up to $120 \mathrm{~km} . \mathrm{h}^{-1}$ and above this speed. Direct flank protection of train path with speed higher $120 \mathrm{~km} \cdot \mathrm{h}^{-1}$ is required:

- from all sidings,

- from all service tracks.

In this case, rolling stock arriving from siding or service track should head to the safety track and probably has low speed at its end (by the buffer stop). Another situation with possibility of higher impact speeds may occur on safety tracks from running tracks (see chapter 1.1.1).

\subsubsection{Mutually Excluded Train Path}

Amongst other conditions, safety and signalling plant of second or higher category has to forbid the simultaneous setting of train path for which the train path with higher speed than $120 \mathrm{~km} \cdot \mathrm{h}^{-1}$ meets, crosses or overlaps with continuation of another train path. This condition is crucial for direct flank protection. If there is no direct flank protection of the train path with speed higher than $120 \mathrm{~km} \cdot \mathrm{h}^{-1}$, one of train paths is not allowed to be set or the speed is restricted up to $120 \mathrm{~km} \cdot \mathrm{h}^{-1}$. Speed restriction depends on possibilities of main signals (what speed can be signalled). In railway station, where restricted speed is used, the restriction brings speed to lower level, than in railway station, where no restriction is needed (with speed of $120 \mathrm{~km} \cdot \mathrm{h}^{-1}$ ). This issue causes regular delay of trains on daily bases, since not even system like KANGO is able to cope with this situation. The only result is to build flank protection switches not only from sidings and service tracks but even from running tracks where threat of the train path with speed higher than 120 $\mathrm{km} \cdot \mathrm{h}^{-1}$ occurs.

\section{Buffer Stop's Design PARAMETERS}

As a crucial parameter for designing buffer stop is its kinetic energy absorbing capacity, thus stopping a rolling stock of certain mass with a certain collision speed. There are various situations of buffer stop's location, therefore it is needed to approach the design individually. Whether the buffer stop is at the end of a dead-end track in station by platform, or ends a safety track (either from sidings, service track or even running tracks). Each situation gives us different speed and different type of train (its mass) that can run into a buffer stop. As mentioned above, amount of kinetic energy that buffer stop is able to absorb is the crucial parameter for its design. Kinetic energy of moving rolling stock can be calculated as sum of the kinetic energy of transitional motion and kinetic energy of rotating parts of the rolling stock (1.). 


\begin{tabular}{||c|c|c||}
\hline Vehicle groups & Vehycle types & $\rho[-]$ \\
\hline \hline \multirow{3}{*}{ Trains } & Regular passengers or freight trains & 0,06 \\
\cline { 2 - 3 } & Electric motor unit & $0,15-0,20$ \\
\hline \multirow{4}{*}{ Cars } & Cars with mechanical traction transition & $0,12-0,15$ \\
\cline { 2 - 3 } & Cars with traction motors & $0,20-0,025$ \\
\cline { 2 - 3 } & Passengers cars & $0,04-0,06$ \\
\cline { 2 - 3 } & Full freight cars & $0,04-0,05$ \\
\cline { 2 - 3 } Locomotives & Empty freight cars & $0,1-0,12$ \\
\cline { 2 - 3 } & Steam & $0,08-0,10$ \\
\cline { 2 - 3 } & Electric & $0,20-0,30$ \\
\hline \multirow{3}{*}{} & Motor & $0,15-0,30$ \\
\hline
\end{tabular}

TABle 1. Coefficient of rotating parts [2]

\begin{tabular}{|c|c|c|c|c|c|c|c|c|c|c|c|}
\hline \multirow{2}{*}{ Speed $\left[\mathrm{km} \cdot \mathbf{h}^{-1}\right.$} & \multirow{2}{*}{ Speed $\left[\mathrm{m} \cdot \mathrm{s}^{-1}\right]$} & \multicolumn{10}{|c|}{ Impact mass $[t]$} \\
\hline & & 100 & 200 & 300 & 400 & 500 & 600 & 700 & 800 & 900 & 1000 \\
\hline 10 & 2,78 & 386 & 773 & 1159 & 1546 & 1932 & 2319 & 2705 & 3091 & 3478 & 3864 \\
\hline 15 & 4,17 & 869 & 1739 & 2608 & 3478 & 4347 & 5217 & 6086 & 6956 & 7825 & 8694 \\
\hline
\end{tabular}

TABLE 2. Examples of kinetic energy [kJ]

(1.)

$$
E_{k i n, c}=E_{k i n, p}+E_{k i n, r}
$$

$$
\begin{aligned}
& E_{k i n, p}=\frac{1}{2} m v^{2} \\
& E_{k i n, r}=\frac{1}{2} I \omega^{2}
\end{aligned}
$$

With substitution equation (2.) and (3.) into equation (1.) and following modification it is possible to calculate kinetic energy of moving rolling stock, using equation (4.).

(4.)

$$
E_{k i n, c}=\frac{1}{2} m(1+\rho) v^{2}
$$

- $E_{k i n, c} \ldots$ total kinetic energy [J];

- $E_{k i n, p} \ldots$ kinetic energy of transitional motion $[\mathrm{J}]$;

- $E_{k i n, r} \ldots$ kinetic energy of rotating parts [J];

- $\mathrm{m}$... weight of rolling stock $[\mathrm{kg}]$;

- $\mathrm{v}$... collision speed $\left[\mathrm{m} . \mathrm{s}^{-1}\right]$;

- I ... moment if inertia $\left[\mathrm{kg} \cdot \mathrm{m}^{2}\right]$;

- $\omega$... angular speed $\left[\mathrm{s}^{-1}\right]$;

- $\rho \ldots$ coefficient of rotating parts [-].

Examples of kinetic energy are given in Table 2

For buffer stop, as a device (structure) that has to work properly and must ensure high level of safety and reliability, we need to involve a safety coefficient in calculations. Therefore, the buffer stop's kinetic energy absorbing capacity has to be determined as follows:

$$
R>=E_{k i n, c} k
$$

- $R$... buffer stop's kinetic energy absorbing capacity $[\mathrm{J}]$;
- $E_{k i n, c} \ldots$ total kinetic energy $[\mathrm{J}]$;

- $k$... safety coefficient [-].

In Table 3 are shown examples of safety coefficient graded by the level of protection and type of train according to Austrian standards [3].

\subsection{Collision Speed}

The collision speed is defined as the maximum permissible speed in which trains may travel when colliding with buffer stop. There are various approaches, how to determine collision speed. German standard DS 80001 [4] use the collision speed based on train type:

- passengers trains: $15 \mathrm{~km} \cdot \mathrm{h}^{-1}$

- freight trains: $10 \mathrm{~km} \cdot \mathrm{h}^{-1}$

Austrian standard DV B 53 [3] use the collision speed based on track type:

- main line trains: $15 \mathrm{~km} \cdot \mathrm{h}^{-1}$

- empty passengers trains or shunting: $10 \mathrm{~km} \cdot \mathrm{h}^{-1}$

Take an example how the collision speed can be calculated. Driver is responsible to make a proper braking according to signals. By error he overlooks a presignal and has no information about decelerating the train. He starts to decelerate at the point of signal with prohibiting signal using the emergency brake. Table 4 displays braking distances (using operating brakes and emergency brake) and speeds of trains at the end of dead-end track (model situation: assuming the distance between signal with prohibiting signal and buffer stop is $100 \mathrm{~m}$ ).

Parameters for Table 4

- * train will stop before the buffer stop,

- Os deceleration - 0,50 m.s ${ }^{-2}$ (2x unit 451/452) [5],

- R, Ex, IC deceleration - 0,45 m.s ${ }^{-2}$ (locomotive $363+8$ cars type Y) [5], 


\begin{tabular}{||l|c||}
\hline Type of train and security level & $k[-]$ \\
\hline Passengers trains & 1,5 \\
\hline Freight trains and shunting & 1,2 \\
\hline $\begin{array}{l}\text { Freight trains and shunting, when it is necessary to } \\
\text { protect various systems which are located behand or } \\
\text { nearby buffer stop }\end{array}$ & 1,5 \\
\hline $\begin{array}{l}\text { Freight trains and shunting, in cases where there are } \\
\text { traffic zones, structures or residential houses located } \\
\text { behind or nearby buffer stop }\end{array}$ & 1,8 \\
\hline Preventing the fall of any train or rolling stock into abyss & 2,0 \\
\hline
\end{tabular}

TABLE 3. Safety coefficient 3]

\begin{tabular}{||l|c|c|c|c|c|c||}
\hline \multirow{2}{*}{$\begin{array}{l}\text { Speed } \\
{\left[\mathbf{k m} \cdot \mathbf{h}^{-1}\right]}\end{array}$} & \multicolumn{3}{|l|}{ Braking distance $[\mathbf{m}]$} & \multicolumn{3}{l}{$\begin{array}{l}\text { Speed at the end of dead-end track } \\
{\left[\mathbf{k m}^{-1}\right]}\end{array}$} \\
\cline { 2 - 7 } & $\mathbf{O s}$ & $\mathbf{R}, \mathbf{E x}, \mathbf{I C}$ & Emergency braking & Os & $\mathbf{R}, \mathbf{E x}, \mathbf{I C}$ & Emergency brake \\
\hline $\mathbf{5 0}$ & 192,90 & 214,33 & 40,19 & 35 & 37 & $*$ \\
\hline $\mathbf{6 0}$ & 277,78 & 308,64 & 57,87 & 48 & 49 & $*$ \\
\hline $\mathbf{7 0}$ & 378,09 & 420,10 & 78,77 & 60 & 61 & 13 \\
$\mathbf{8 0}$ & 493,83 & 548,70 & 102,88 & 71 & 72 & 43 \\
$\mathbf{9 0}$ & 625,00 & 694,44 & 130,21 & 82 & 83 & 61 \\
\hline $\mathbf{1 0 0}$ & 771 & 857,34 & 160,75 & 93 & 94 & $*$ \\
\hline
\end{tabular}

TABLE 4. Deceleration of trains

\begin{tabular}{||l|l|l||}
\hline $\begin{array}{l}\text { Buffer Stop } \\
\text { Type }\end{array}$ & $\begin{array}{l}\mathbf{6} \text { cars of } \\
\mathbf{1 5} \mathbf{~ t}\end{array}$ & $\begin{array}{l}\mathbf{1} \text { car of } \\
\mathbf{8 0 ~ t ~}\end{array}$ \\
\hline $\begin{array}{l}\text { Rail buffer } \\
\text { stop }\end{array}$ & $1,0 \mathrm{~km} \cdot \mathrm{h}^{-1}$ & $1,6 \mathrm{~km} \cdot \mathrm{h}^{-1}$ \\
\hline $\begin{array}{l}\text { Concrete type } \\
\text { "SUDOP" }\end{array}$ & $0,7 \mathrm{~km} \cdot \mathrm{h}^{-1}$ & $1,1 \mathrm{~km} \cdot \mathrm{h}^{-1}$ \\
\hline $\begin{array}{l}\text { Concrete type } \\
\text { "DSB" }\end{array}$ & $1,0 \mathrm{~km} \cdot \mathrm{h}^{-1}$ & $1,6 \mathrm{~km} \cdot \mathrm{h}^{-1}$ \\
\hline
\end{tabular}

TABlE 5. Resistances of buffer stops used in Czech Republic [1]

- emergency brake deceleration $-2,40 \mathrm{~m} \cdot \mathrm{s}^{-2}$.

\section{Types of Buffer Stops}

\subsection{FiXed BUfFER STOPS WITH MECHANICAL BUMPERS}

Fixed (rigid) buffer stop is one of the most used types of buffer stops considering its history as an oldest one. Construction of fixed buffer stop consists of a block or frame fixed rigidly to the rails or the ground. As other constructions, fixed buffer stop has its pros and cons. One of advantages is that it can be placed at the end of the dead-end track, thus it does not reduce the usable length of the track. However, in this case cons prevail, such as low resistance and manner of deceleration. Resistances (as a state of usability) of fixed buffer stops used in Czech Republic are shown in Table 5

If the mass or speed is higher, either the buffer stop or the train is destroyed. Assuming both buffer stop and rolling stock frame will be reinforced significantly, and therefore cannot deform, the deceleration

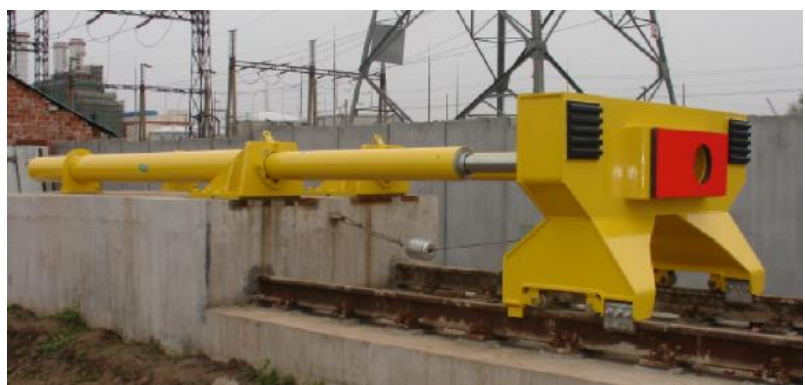

Figure 1. Example of hydraulic buffer stop (Oleo comp.) 7

is unacceptable (see Table 6).

\subsection{Hydraulic Buffer Stop (Fixed Buffer Stop with Hydraulic BuMPERS)}

Hydraulic buffer stops are similar in construction to fixed. Consist of a block or frame fixed rigidly to the rails or the ground. Hydraulic buffer stops absorb kinetic energy in gradual manner (depends on the type of the hydraulic bumpers). If the energy is higher than the bumper is able to absorb, buffer stop is destroyed.

PARAMETERS of the buffer stop on Figure 1:

- kinetic energy absorbing capacity: $2688 \mathrm{~kJ}$,

- bumpers stroke: $2400 \mathrm{~mm}$.

\subsection{Friction Buffer Stop}

Friction buffer stop is the most effective way to stop moving rolling stock. The way of absorbing the kinetic energy, thus decelerating the rolling stock is the most efficient and safe. Not only the train decelerates in 


\begin{tabular}{|c|c|c|c|c|c|}
\hline \multirow{3}{*}{$\begin{array}{l}\text { Impact speed } \\
{\left[\mathrm{km} \cdot \mathrm{h}^{-1}\right]}\end{array}$} & \multirow{3}{*}{$\begin{array}{l}\text { Impact speed } \\
{\left[\mathrm{m} . \mathrm{s}^{-1}\right]}\end{array}$} & \multicolumn{4}{|c|}{ Stroke of mechanical bumpers $[\mathrm{mm}][\mathbf{6}]$} \\
\hline & & \multicolumn{2}{|c|}{75} & \multicolumn{2}{|c|}{105} \\
\hline & & $\begin{array}{l}\text { Decelartion } \\
{\left[\mathrm{m} . \mathrm{s}^{-2}\right]}\end{array}$ & Overload & $\begin{array}{l}\text { Decelartion } \\
{\left[\mathrm{m} \cdot \mathrm{s}^{-2}\right]}\end{array}$ & Overload \\
\hline 5 & 1,39 & 6,43 & $0,66 \mathrm{~g}$ & 4,59 & $0,47 \mathrm{~g}$ \\
\hline 10 & 2,78 & 25,72 & $2,62 \mathrm{~g}$ & 18,37 & $1,87 \mathrm{~g}$ \\
\hline 15 & 4,17 & 57,87 & $5,90 \mathrm{~g}$ & 41,34 & $4,21 \mathrm{~g}$ \\
\hline
\end{tabular}

TABLE 6. Deceleration of train and overload on passengers on impact the fixed buffer stop

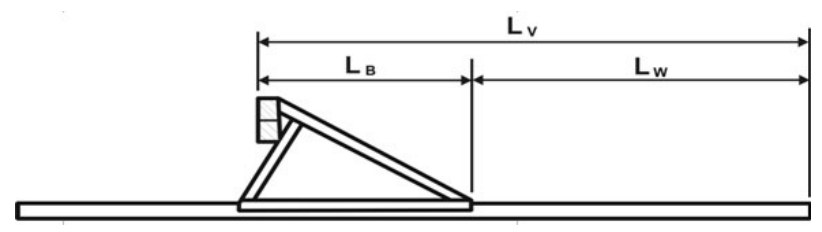

FiguRE 2. Length needed for buffer stop placement and to ensure braking distance 8 ]

gradual manner over a longer distance (time period), but the kinetic energy absorbing capacity could be very high. Friction buffer stop generally consist of rigid steel frame with buffers, connected to rails using arresting devices (friction jaws). In case of collision, kinetic energy is transformed into heat by means of friction. Therefore, energy absorbing capacity of friction buffer stop depends on the number of friction jaws, friction coefficient resp. braking force of jaws and length of braking. Nevertheless, there is a disadvantage. Friction buffer stop needs a braking distance, therefore cannot be placed at the end of the deadend track and shortens its usable length. Moreover the track behind the buffer stop needs to be horizontally straight and contain no welds and joints or other obstacles over rails.

NOTES for Figure 2

- $L_{V} \ldots$ length needed for buffer stop placement and to ensure braking distance;

- $L_{B} \ldots$ buffer stop length;

- $L_{W} \ldots$ maximum braking distance.

Three types of friction buffer stops can be named:

- friction buffer stop (without additional brakes), see Figure 3

- friction buffer stop with additional brakes, see Figure 4

- friction buffer stop with hydraulic bumpers (with/without additional brakes).

NOTES for Figure 3

(1.) Collision triangle;

(2.) Breaking devices;

(3.) Buffers;

(4.) Device for returning the buffer stop to working position after collision;

(5.) Reinforcement;

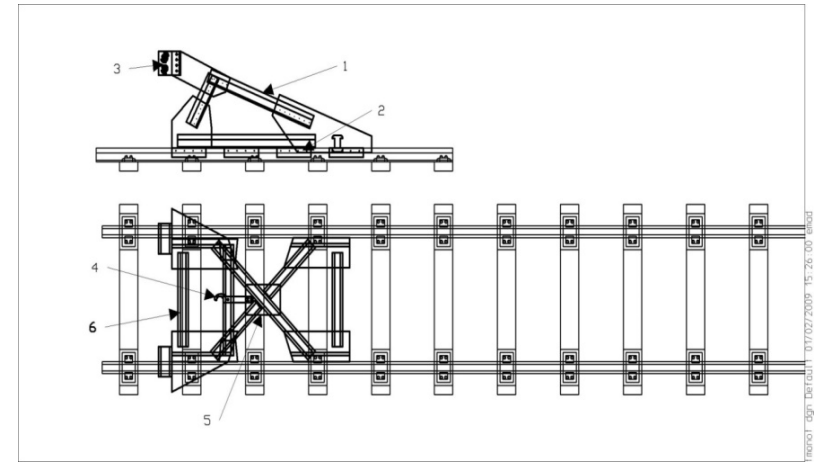

Figure 3. Friction buffer stop without additional brakes 8

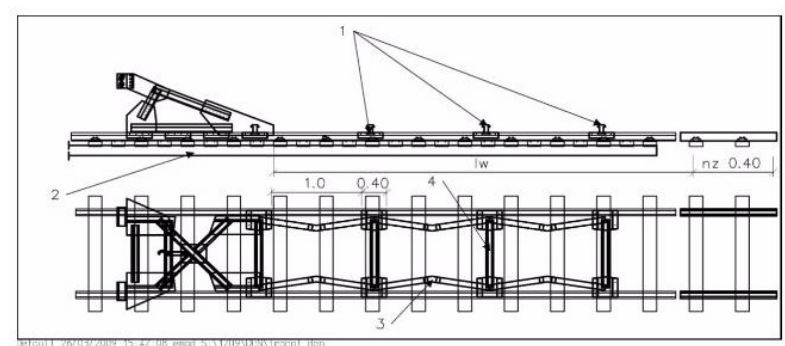

FiguRE 4. Friction buffer stop with additional brakes [8]

(6.) Reinforcement.

NOTES for Figure 4

(1.) Additional arresting devices for added braking;

(2.) Steel profile below rails for reinforcement of the track;

(3.) Jointed connection belts between arresting devices;

(4.) Lateral connection between arresting devices.

\subsubsection{BRAKING FORCE}

Braking force is the determining factor of friction buffer stop. As mentioned above, buffer stop must absorb high amount of kinetic energy. Calculation of breaking force in case of friction buffer stops depends on numbers of arresting devices, braking force of each arresting device and maximum braking distance.

$$
R=n_{b} F_{b} L_{W}
$$

- $R$... buffer stop's kinetic energy absorbing capacity $[\mathrm{J}]$; 


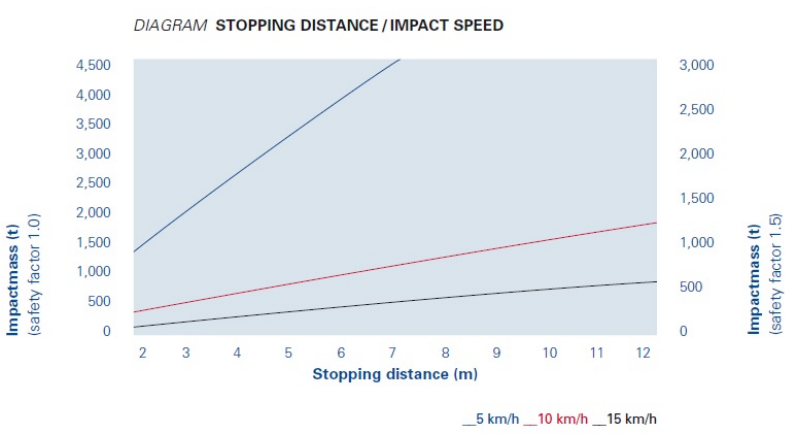

Figure 5. RAWIE 16 ZEB, stopping distance/impact speed/impactmass diagram, safety coefficient 1,0 and 1,5 [9]

- $n_{b} \ldots$ number of arresting devices [-];

- $F_{b} \ldots$ braking force of a single arresting device $[\mathrm{N}]$;

- $L_{W} \ldots$ maximum braking distance $[\mathrm{m}]$.

Braking force of friction buffer stop with additional brakes comes from formula up there. Formula is modified considering braking force of additional brakes while braking distance of each additional arresting device is included separately.

$$
R=\sum_{i=1}^{n_{Z}} 2 F_{b i} L_{W i}
$$

- $R \ldots$ buffer stop's kinetic energy absorbing capacity $[\mathrm{J}]$

- $n_{Z} \quad \ldots \quad$ number of a pair of additional arresting devices [-];

- $F_{b i} \ldots$ braking force of a single arresting device, based on a braking distance [N];

- $L_{W i} \ldots$ length of braking distance of a pair of arresting devices [m].

An example of friction buffer stop's braking effectiveness is shown in Figure 5 (friction buffer stop without additional brakes with absorbing capacity of $\left.640 \mathrm{~kJ} \cdot \mathrm{m}^{-1}\right)$.

\section{Conclusion}

Many aspects have to be taken in account while designing buffer stop. One has to consider its location - ending of dead-end track in railway station, ending safety track from sidings, service track or running track. Every scenario brings different requirements such as type of train, collision speed, impact mass etc. In general, three types of buffer stops are used, depending of the principle of absorbing the energy. Fixed buffer stops are more than useless for higher collision speeds considering its manner of deceleration and its resistances. However, using fixed buffer stops is justified e.g. in shunting yards, where are low speeds and no passengers on board. As more appropriate ending of dead-end track is usage of hydraulic or friction buffer stop. Resistances of those types are much higher than fixed buffer stops. Both this construction decelerates train in gradual manner and no harm to the rolling stock or buffer stop itself is done if the design was precise.

\section{ACKNowledgements}

The paper was created with support of the project no. LO1408 "AdMaS UP - Advanced Materials, Structures and Technologies" supported by the Ministry of education, youth and sports within the targeted support of program "National program for sustainability I".

\section{REFERENCES}

[1] ČD Ž9 Železniční spodek, Vzorový list železničního spodku, Zarážedla. České dráhy, s.o., Divize dopravní cesty, o. z. Praha, 2001. In effect from: 2002-04-01.

[2] J. Široký. Mechanika v dopravě I âĂŞ kolejová vozidla [online]. Updated 2003, [2016-01-13], http://homen.vsb.cz/ s1i95/mvd/Skr_MvD.pdf

[3] 'OBB: DV B 53. Die Gestaltung von Oberbauanlagen.

[4] Db: Ds 800 01. bahnanlagen entwerfen - allgemeine entwurfsrichtlinien.

[5] L. Fiala. Provozni dopady aplikace ochranných vzdáleností podle TNŽ 342620 - Master thesis. University of Pardubice, Pardubice. Supervisor Pavel Drda, 2010.

[6] TNŽ 282605 Kolejová vozidla - železniční. Trubkové nárazníky s korýtkovým vedením. Typy, základní parametry, technické požadavky, zkoušení. Nymburk: ČSD, 1991. In effect from: 1991-07-01.

[7] Oleo end stops. OLEO International [online]. Updated 2015-07-09, [2015-11-07], http://www.oleo.co.uk/products/end-stops

[8] ISRAEL RAILWAYS LTD. Railway buffer stops planning guidlines [online], 2009. Updated 2013, [201511-10], http://www.iroads.co.il/sites/default/ files/imce/ir_buffer_stops_guidelines.doc.

[9] Rewie Bahntechnik Strassenbahn. RAWIE GmbH \& Co. KG [online]. Updated 2015-08-20, [2015-11-07], http://www.rawie.de/index.php/de/bahntechnik/ strassenbahn 